\title{
ディスコチックネマチック相の光重合により得られる 高分子フィルムの秩序パラメータ
}

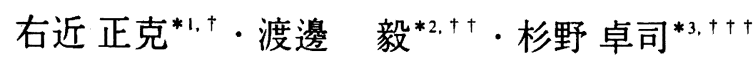 \\ 物部 浩達 ${ }^{* 3} \cdot$ 清水 洋*3
}

（受付 2002 年 6 月 20 日・審査終了 2002 年 9 月 24 日）

\begin{abstract}
要 旨 長鎖末端にアクリル基を有するトリフェニレン誘導体 1 を合成，そのディスコチックネマチッ ク相における光重合の進行と，系の秩序パラメータの変化を時間分解赤外スペクトルの測定によって調べ た。秩序パラメー夕はV Vij らによる赤外吸収帯の 2 色性を配向に対して比較する方法によって, トリフェ ニレンおよび周辺に置換したカルボニル基について局所的秩序パラメー夕を見積もった．その結果，分子 中心のトリフェニレン部は光重合の進行とともに系の秩序パラメータは重合終了時まで減少するが,特に, 光照射量にして約 $10 \mathrm{mJcm}^{-1}$ に達した時点で全変化量の約 $70 \%$ に相当する大きな減少を示し, それ以後 は渐次滅少する傾向を示すことがわかった，光重合は約 $70 \%$ のアクリル基消費を超えて進行しないが, 秩序パラメータの隇少を抑えるためには $50 \%$ 程度のアクリル基消費過程を制御することが重要であるこ とが示された.
\end{abstract}

\section{1 粕言}

高分子主鎖ないしはそれに結合した官能基がある均一 配向をもつような配向性高分子の実現は高分子の高度な 機能化を達成する上で極めて重要と考えられる，そのよ うな高分子には導電性, フォトクロミズム, 光非線形性, 発光などさまざまな機能において研究がなされている". このような流れの中, 分子配向の制御性に優れる液晶 を利用した分子配向性高分子を得る試みが 1980 年代の 終わり頃に始まった．Broerらは分子内にアクリル基な どの重合性官能基を有する棒状液晶のネマチック相やス メクチック $\mathrm{A}$ 相における光重合, 熱重合を行い, 液晶 状態において示された複屈折が重合後も保持されている ことなどを見いだした2) -41. これらの研究はその後異方 性をもつ光および機械特性が制御された高分子材料に関

*1 (財) 化学技術戦略推進機構分子協調材料集中研究体大阪 (区563-8577 池田市緑丘 1-8-31)

*2 JSR (株) 精密電子研究所（-510-8552 四日市市川尻町 100）

*3 (独) 産業技術総合研究所人間系特別研究体メソフェースエ 学研究グループ (『563-8577 池田市緑丘 1-8-31)

†現所属機関 - 所在地: JSR (株) 光学材料事業部光機能材料 部(®104-8410 東京都中央区築地 2-11-24)

†現所属機関 - 所在地: JSR Microelectronics, Inc. (Sunnyvale, CA 94089 U.S.A.)

†十現所属機関・所在地: (独) 産業技術総合研究所人間系特別 研究体刺激応答材料研究グループ（\$563-8577 池田市緑 丘 1-8-31)
する研究へと展開している51.

一方，ディスコチック液晶においても，光透過制御材 料の観点から同様の研究が行われてきた勿，特筆すべ きは，ディスコチックネマチック相を用いて液晶フラッ トパネルディスプレーのもつ本質的な問題点であった狭 い視野角を補償することが可能な高透明性高分子フィル ムの開発に成功していることで，河田らはディスコチッ クネマチック相における分子配向を基板表面の工夫によ って光透過線を形成するように配向させ，その状態で光 重合を行うことによって高度に制御された分子配向をも つ高分子フィルムの開発を行った ${ }^{81,9}$.

ディスコチック液晶では, 90 年代の半ば頃その特徴 的な分子配向であるカラム構造をもつカラムナー中間相 の一つにおいて $10^{-1} \mathrm{~cm}^{2} \mathrm{~V}^{-1} \mathrm{~s}^{-1}$ という高速のホール移 動度が観測され ${ }^{(0)}$, それ以後大きな $\pi$ 電子共役系を有す るディスコチック液晶に新しい有機半導体としての注目 が注がれるようになった(1)ー(4).

しかしながら，液晶あるいは中間相において高速の電 荷移動度が観測されたとしても実用面ではその粘性や流 動的状態は支持体を必要とすることになる．その点, 高 速の電荷移動度を有するディスコチック液晶を光重合な どの手法でその分子配向秩序が保持された高分子フィル ム化を行うことは, 電荷移動度を損なわずフィルム化す ることによって多様な用途に応用される技術となる可能 性がある。このような高機能性高分子フィルムには, 高 度に制御された分子配向秩序がナノメートルスケールで 


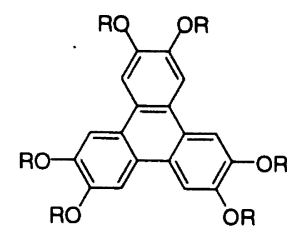

1

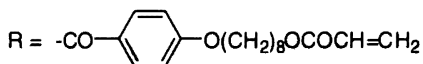

Scheme 1

構築されることによる機能の飛躍的向上も期待される. しかしながら，筆者らの知る限り，ディスコチック液晶 の光重合に関する秩序パラメータなどの定量的実験結果 の報告はない.

先に筆者らは，分子内化学結合をモニタリングし，そ の化学結合の秩序パラメー夕を求める $\mathrm{Vij}$ らの赤外 2 色 法(5) を用いて局所的秩序パラメー夕を評価した結果,

重合性ディスコチック液晶の示すディスコチックネマチ ック $\left(\mathrm{N}_{\mathrm{D}}\right)$ 相について初めて液晶配向が光重合によっ て変化することを報告した ${ }^{16}$.

本報では, 同じ光重合性官能基を有するトリフェニレ ン液晶の $\mathrm{N}_{\mathrm{D}}$ 相において, 光重合による分子配向の変化 と重合進行との関係を同様の赤外 2 色法により得た秩序 パラメータから考察した。

\section{2 実験}

\section{1 試料}

重合性トリフェニレン液晶性化合物 1 は文献記載の方 法を基本に合成した ${ }^{17,18} .1$ は $91^{\circ} \mathrm{C}$ と $166^{\circ} \mathrm{C}$ の温度範囲 で $\mathrm{N}_{\mathrm{D}}$ 相を示す $\left(\right.$ Scheme 1) ${ }^{16}$.

\section{2 重合および赤外スペクトルの測定}

モノマー液晶 1 は, 開始材として市販のイルガキュア 651 を $1 \mathrm{wt} \%$ 混合した試料とし，これを高圧水銀ランプ $\left(1 \mathrm{mWcm}^{-1}\right)$ を用いて $\mathrm{i}$ 線バンドパスフィルターを介し て光照射し, 重合させた。この際, 赤外スペクトルを測 定するために，赤外光波長域で透明なフッ化バリウム板 (18 mm 径) に試料を挟み、これを温度制御可能なホッ トステージに挿入，紫外線照射しながら時間分解赤外ス ペクトルの測定を行った。測定装置の概要を Fig. 1 に図 示した. 得られたスペクトル変化は以下に述べる $V_{i j} ら$ の赤外 2 色法によってメソーゲンを構成する化学結合の 秩序パラメータとして算出, 重合の進行と変化する秩序 パラメータの挙動を検討した. 2 枚のフッ化バリウム板 間では $\mathrm{N}_{\mathrm{D}}$ 相はホメオトロピック配向する傾向が見られ た.

\section{3 秩序パラメータの算出 ${ }^{(5)}$}

得られた赤外スペクトルからの秩序パラメータの算出 は以下の Vijらの手法によった。

秩序パラメータ $S$ は以下の式から算出される. 式(1)

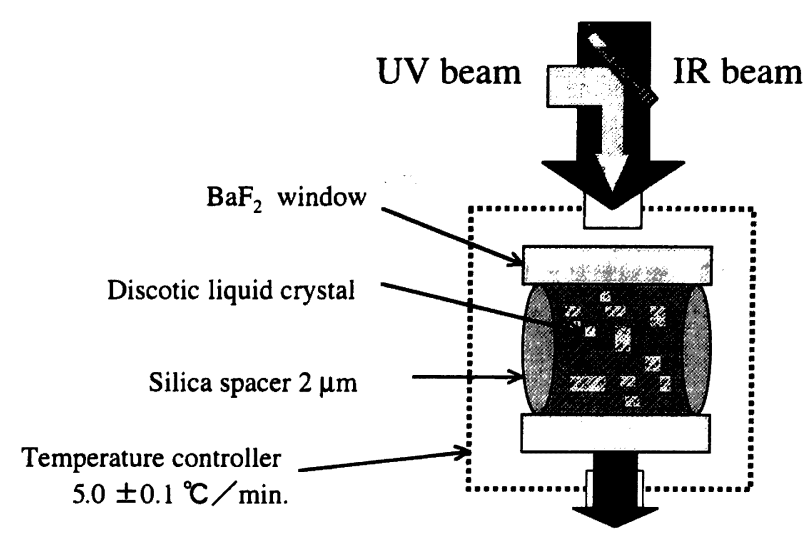

Fig. 1. Schematic representation of the experimental set-up for the measurements of infrared spectra during photopolymerization by UV light.

は $\mathrm{C}=\mathrm{C}$ 伸縮振動に対して, 式(2) は $\mathrm{C}=\mathrm{O}$ 伸縮振動の 各赤外吸収帯に適応される。

$$
\begin{aligned}
& S=2\left(I_{\mathrm{D}} / I_{1}-1\right) \\
& S=1-I_{\mathrm{D}} / I_{1}
\end{aligned}
$$

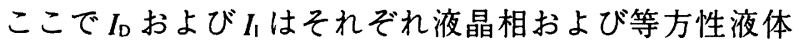
における赤外吸収帯の強度である。ID $I_{\mathrm{D}}$ および I 性の赤外ビームを用いて測定したスペクトルからは以下 のように定義される.

$$
\begin{aligned}
& I_{\mathrm{D}}=\cos ^{2} \psi<\sin ^{2} \theta>+1 / 2 \sin ^{2} \psi<1+\cos ^{2} \theta> \\
& I_{\mathrm{I}}=\cos ^{2} \psi<\sin ^{2} \theta>{ }_{\mathrm{I}}+1 / 2 \sin ^{2} \psi<1+\cos ^{2} \theta>_{\mathrm{I}} .
\end{aligned}
$$

ここで， $\psi$ は相当する赤外吸収の遷移双極子の方向と 分子平面の成す角であり， $\theta$ は照射光と分子平面に垂 直な軸が成す角である.

秩序パラメータ $S$ は $S=1-3 / 2<\sin ^{2} \theta>$ で定義され るので等方性液体では $\left\langle\sin ^{2} \theta\right\rangle_{1}=2 / 3$ および $\left\langle\sin ^{2} \theta\right\rangle_{1}$ $=1 / 3$ となる.フェニル基およびトリフェニレン骨格の $\mathrm{C}=\mathrm{C}$ 面内伸縮振動に対しては $\psi=90$ を仮定すると $S=$ $2\left(I_{\mathrm{D}} / I_{\mathrm{I}}-1\right)$, ベンゾイル基およびアクリル基の $\mathrm{C}=\mathrm{O}$ 伸 縮振動は $\psi=0$ を仮定すると $S=1-I_{\mathrm{D}} / I_{1}$ となる.

この手法は赤外偏光板を用いず秩序パラメー夕を評価 が可能であるが，測定に用いる液晶試料はある程度の大 きさのホメオトロピックあるいはプレーナー配向をもっ た均一配向ドメインを必要とする。

\section{3 結果と考察}

\section{1 重合性モノマー液晶の秩序パラメータ}

Fig. 2 に 1 の液晶相における赤外吸収スペクトルを示 す。秩序パラメータの評価には，これらの吸収帯のうち フェニル基およびトリフェニレン骨格の $\mathrm{C}=\mathrm{C}$ 面内伸縮 振動には $1606 \mathrm{~cm}^{-1}$ の吸収帯を, また $\mathrm{C}=\mathrm{O}$ 伸縮振動に ついては, ベンゾイル基には $1736 \mathrm{~cm}^{-1}$ を，アクリル基 


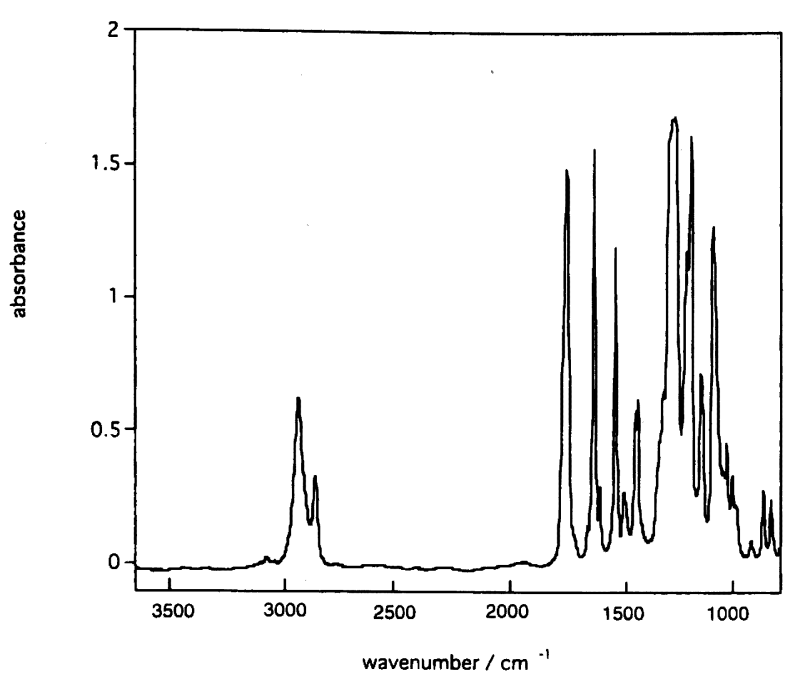

Fig. 2. Infrared specrum of the monomeric mesogen 1 in $\mathrm{N}_{\mathrm{D}}$ phase $\left(120^{\circ} \mathrm{C}\right)$.

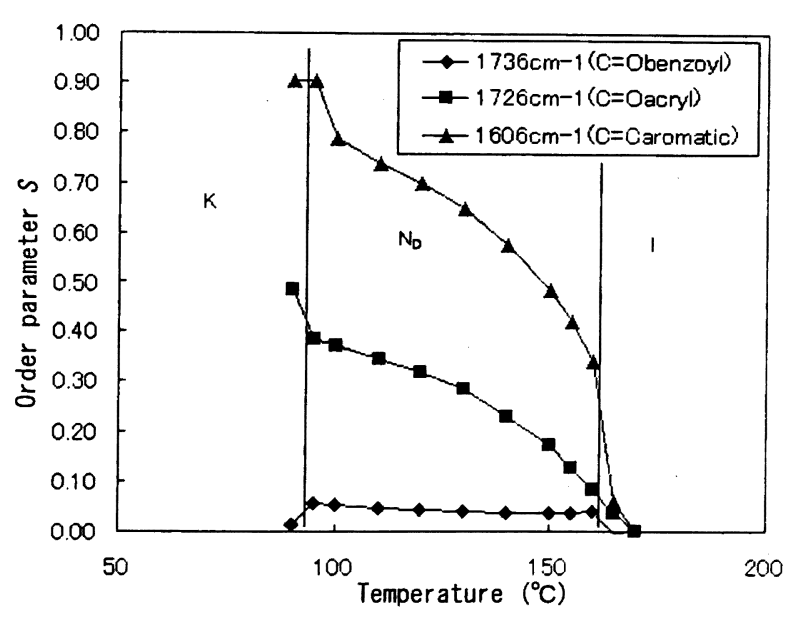

Fig. 3. Temperature dependence of the local order parameters in $N_{D}$ phase of 1 .

\section{には $1726 \mathrm{~cm}^{-1}$ それぞれ用いた。}

Fig. 3 に得られたメソーゲン分子の局所的秩序パラメ 一タの昇温時の温度依存性を示す。トリフェニレンおよ びフェニル基の秩序パラメー夕は本液晶相の秩序パラメ 一タに近いと考えられるが, それは温度低下とともに増 大している.この挙動は, 以前に報告した降温時測定の 結果と同様であった。これは相当する長鎖アルキル基を もつ誘導体の挙動 ${ }^{19}$ お よび棒状液晶系の挙動と同様の ものであり ${ }^{201,211}$ ，ネマチック相の高配向秩序をもつ高分 子を得るためには液晶相の低温度領域での重合が好まし いと考えられる。秩序パラメータは $\mathrm{N}_{\mathrm{D}}$ 相の温度領域で 0.4 から 0.8 まで変化し, 高温側では同じ液晶相でもそ の秩序度に大きな差が存在しているといえる。この秩序 パラメータの值は, 先に報告したフッ化バリウム板にポ

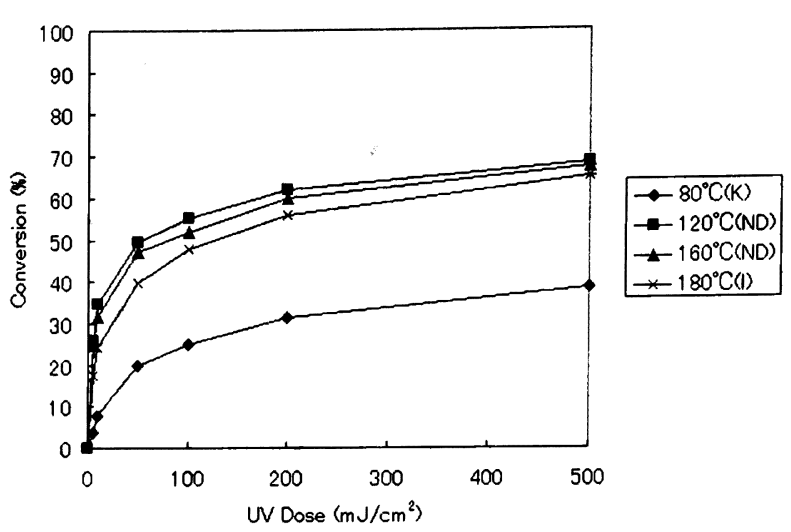

Fig. 4. Relation of the acryl conversion to the photon flux for the photopolymerization of $\mathbf{1}$.

リイミドをコートした場合よりも若干小さい(6).これは 先の報告では等方性液体からの冷却過程で測定を行って おり, 基板表面のポリイミド膜との相互作用が顕著に効 いた結果と解釈され得る。

一方, カルボニル基については小さな秩序パラメータ を示すことがわかる。これはカルボニル基が結合軸周り に回転可能であることを反映した結果と考えられるが, より分子中心に近いベンゾイル基の $\mathrm{C}=\mathrm{O}$ 結合がほとん ど配向性をもたないと考えられる結果であるのに対し， アクリレート部分の $\mathrm{C}=\mathrm{O}$ 結合はある程度の配向性が認 められ, かつ芳香環の場合と同様の温度依存性を示すこ とは興味深い. $N_{D}$ 相では長鎖末端の電気双極子間で弱 い分子間相互作用が存在しているのかもしれない.

\section{2 光重合と秩序パラメータ}

Fig. 4 に光重合における照射光量と重合の進行に伴う アクリル基の消費量との関係を示す. $50 \mathrm{mJcm}^{-2}$ の照射 光量ではすでに $50 \%$ のアクリル基が消費され，その後 数百 $\mathrm{mJcm}^{-2}$ の照射で $70 \%$ 程度までアクリル基が消費 されることがわかった.この傾向は結晶相, $\mathrm{N}_{\mathrm{D}}$ 相および 等方性液体で同様であるが, 結晶相では消費量そのもの が低い.これは重合反応に必用なアクリル基どうしの出 会いの頻度が結晶中では大きく制限されるためと考えら れる。また， $\mathrm{N}_{\mathrm{D}}$ 相では等方性液体よりも若干大きな消 費量を示すことからネマチック配向が長鎖末端のアクリ ル基間の衝突頻度を大きくしていることが示唆される.

一方，アクリル基の消費と秩序パラメータの関係を C $=\mathrm{C}$ 伸縮振動をモニターすることで得られた結果が Fig. 5 である. 光照射のアクリル基消費に対する温度依存性 はほとんど認められないが， ND 相では $50 \%$ のアクリル 基消費によって 0.15 程度の秩序パラメー夕低下が起こ ることがわかった，興味深いことは， $\mathrm{N}_{\mathrm{D}}$ 相ではその温 度にかかわらずアクリル基の消費量と秩序パラメータの 低下がほとんど一致していることで, 重合前の秩序パラ 


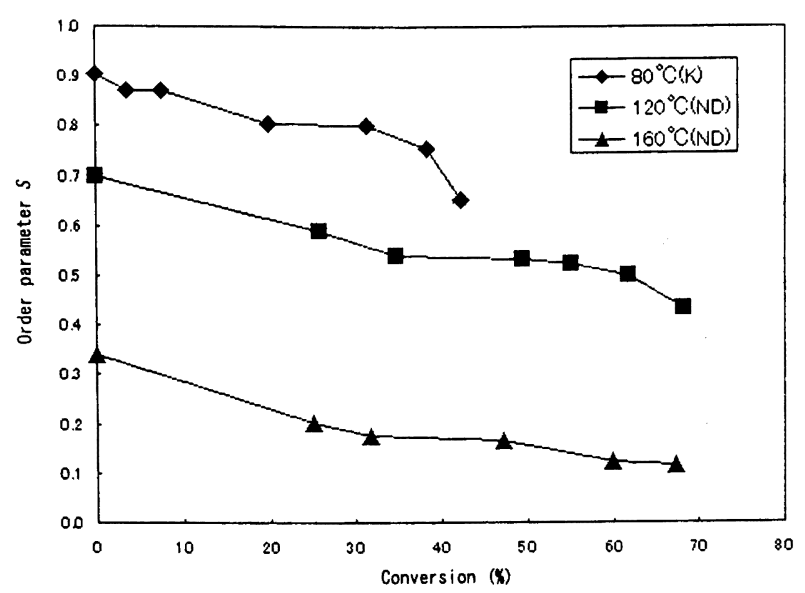

Fig. 5. Relation of the local order parameters to the acryl conversion monitored by the $\mathrm{C}=\mathrm{C}$ stretching band.

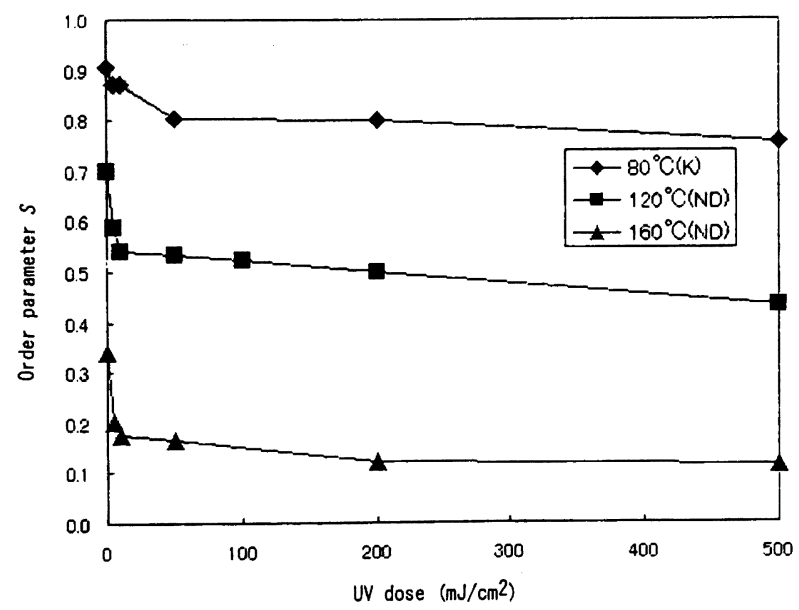

Fig. 6. Photon flux dependence of the local order parameters in the photopolymerization of $N_{D}$ phase of 1.

メータが重合後に比率的な低下を示すものではないこと である。このことは高い秩序パラメータをもつ高分子フ イルムを作製する場合に，液晶相の低温領域で重合を行 うことがより有利であることを強く示唆している.また, 重合性の棒状液晶系についても同様のことが報告されて いる22).

光照射量と秩序パラメータの関係を Fig. 6 に示す. 本 実験条件における結果は, $10 \mathrm{mJcm}^{-2}$ の照射光量でほほ 秩序パラメータの低下が終わっているのがわかる，結晶 では秩序パラメータの低下はよりゆるやかに起こること から重合進行時に分子が互いに動くことの可能な液晶状 態とそれが困難な結晶固体との差が反映していると考え られる。これらのことは, 一つのメソーゲン分子に六つ もの重合性官能基をもつ場合は，50\% 程度の官能基消 費でほとんど得られる高分子フィルムの分子配向秩序が 決められることを示している.

\section{4 結 論}

すべての長鎖末端に重合性官能基（アクリル基）をも つ液晶性トリフェニレン誘導体は $\mathrm{N}_{\mathrm{D}}$ 相を示し,この化 合物を液晶状態で光重合し得られた高分子フィルムの配 向の乱れを定量的に評価するために秩序パラメータを測 定した. その結果, 高い秩序を維持するためにはより低 温の高い秩序パラメータを示す液晶状態で重合を行うこ とが重要であることがわかった.また, 重合進行時, $50 \%$ 程度のアクリル基消費の時点ですでにフィルムのもつ配 向秩序が決定されてしまうことが見いだされた。このこ とから，このような手法でより配向乱れの少ない高分子 フィルムを得るためには重合進行時, 最初の $50 \%$ 程度 のアクリル基消費をどのように制御するかが重要である ことが示唆された。これらの結果は，ディスコチック液 晶の光重合に関する数少ない定量的な実験結果として興 味深い.

謝 辞 本研究は, 平成 7 年度から平成 13 年度の 5 年間実施さ れた通商産業省（現経済産業省）の産業科学技術研究開発プロジ エクトである「独創的高機能材料創製技術の研究開発」における 「分子協調材料の研究開発」において挙げられた成果を元にしてい る。経済産業省ならびにNEDO（新エネルギー・産業技術総合開 発機構）に感謝する。

\section{文献}

1) "Functional Organic and Polymeric Materials", T. H. Richardson ed., Wiley, Chichester (2000).

2) D. J. Broer, H. Finkelmann, and K. Kondo, Makromol. Chem., 189, 185 (1988).

3) D. J. Broer, J. Lub, and G. N. Mol, Macromolecules, 26, 1244 (1993).

4) D. J. Broer, G. N. Mol, and G. Challa, Polymer, 32, 690 (1991).

5) R. A. M. Hikmet, B. H. Zwerver, and J. Lub, Macromolecules, 27, 6722 (1994)

6) C. D. Favre-Nicolin and J. Lub, Macromolecules, 29, 6143 (1996).

7) C. D. Favre-Nicolin, J. Lub, and P. van der Sluis, Adv. Mater., 8, 1005 (1996)

8) M. Okazaki, K. Kawata, H. Nishikawa, and M. Negoro, Polym. Adv. Technol., 11, 398 (2000)

9) K. Kawata, Chem. Rec., 2, 59 (2002).

10) D. Adam, P. Schuhmacher, J. Simmerer, L. Häussling, K. Siemensmeyer, K. H. Etzbach, H. Ringsdorf, and D. Haarer, Nature, 371, 141 (1994)

11) A. M. van de Craats, J. M. Warman, K. Müllen, Y. Geerts, and J. D. Brand, Adv. Mater., 10, 36 (1998).

12) F. Garnier, R. Hajlaoui, A. El Kassmi, G. Horowitz, L. Laigre, W. Porzio, M. Armanini, and F. Provasoli, Chem. Mater., 10, 3334 (1998).

13) A. M. van de Craats, J. M. Warman, A. Fechtenkötter, J. D. Brand, A. M. Harbison, and K. Müllen, Adv. Mater., 11, 1469 (1999).

14) K. Ban, K. Nishizawa, K. Ohta, A. M. van de Craats, J. M. Warman, I. Yamamoto, and H. Shirai, J. Mater. Chem., 11, 321 (2001).

15) G. Kruk, A. Kocot, R. Wazalik, and J. K. Vij, Liq. Cryst., 14, 807 (1993). 
16) M. Ukon, T. Sugino, T. Watanabe, H. Monobe, and Y. Shimizu, Macromol. Mater. Eng., 287, 698 (2002).

17) C. D. Favre-Nicolin, J. Lub, and P. van der Sluis, Mol. Cryst. Liq. Cryst., 299, 157 (1997).

18) N. H. Tinh, H. Gasparoux, and C. Destrade, Mol. Cryst. Liq. Cryst., 9, 471 (1981).

19) H. Monobe, S. Mima, T. Sugino, Y. Shimizu, and M. Ukon, Liq.
Cryst., 28, 1253 (2001).

20) W. L. McMillan, Phys. Rev. A: At., Mol., Opt. Phys., 4, 1238 (1971).

21) R. L. Humphries, P. G. James, and G. R. Luckhurst, J. Chem. Soc., Faraday Trans. 2, 68, 1031 (1972).

22) J. Kawamura, H. Hasebe, N. Obi, and Y. Shimizu, Mol. Cryst. Liq. Cryst. Sci. Technol., Sect. A, 368, 3905 (2001).

Order Parameters of the Film Prepared by Photopolymerization of a Discotic Mesogen in Discotic Nematic Phase

Masakatsu Ukon, ${ }^{* 1, \dagger}$ Tsuyoshi Watanabe, ${ }^{* 2 .}{ }^{\dagger}$ Takushi Sugino, ${ }^{* 3,{ }^{\dagger} \dagger}$ Hirosato Monobe, ${ }^{* 3}$ and Yo Shimizu ${ }^{* 3}$

${ }^{*}$ Mesophase Materials Laboratory, Japan Chemical Innovation Institute (Midorigaoka, Ikeda, Osaka 563-8577, Japan)

${ }^{* 2}$ Fine Electronics Research Laboratories, JSR Corporation (Kawajiri, Yokkaichi, Mie 510-8552, Japan)

${ }^{* 3}$ Mesophase Technology Research Group, Special Division for Human Life Technology, National Institute of Advanced Industrial Science and Technology (Midorigaoka, Ikeda, Osaka 563-8577, Japan)

A triphenylene derivative possessing an acryl group at the peripheral six long chains was synthesized, and the order parameter change during the progress of photopolymerization was investigated by the infrared dichroic method. The $\mathrm{C}=\mathrm{C}$ and $\mathrm{C}=\mathrm{O}$ stretching vibrational bands of the mesogenic molecule were monitored for the evaluation of (local) order parameters. It was found that the order parameter for the triphenylene core decreases up to $70 \sim 80 \%$ of the initial value with the progress of photopolymerization and the decrease continues till the termination of polymerization (ca. $30 \%$ of the residual acryl group). The order parameter shows a rapid decrease at the initial stage of polymerization followed by a gradual declination. On the other hand, the order parameter of the $\mathrm{C}=\mathrm{O}$ moieties of the mesogen did not change much in contrast to that of the aromatics, and the value is far smaller. It was shown that the polymerization extent should be controlled at ca. $50 \%$ of the acryl residue to obtain the polymer film of a well-aligned nematic order.

KEY WORDS Photopolymerization / Discotic Liquid Crystal / Order Parameter / Discotic Nematic Phase / Triphenylene /

(Received June 20, 2002: Accepted September 24, 2002)

[Kobunshi Ronbunshu, 59(12), 787-791 (2002)]

\footnotetext{
${ }^{\dagger}$ Present address: Opto-Functional Materials Department, JSR Corporation (Tsukiji, Chuo-ku, Tokyo 104-8410, Japan)

${ }^{\dagger}{ }^{\dagger}$ Present address: JSR Microelectronics, Inc. (North Mathilda Ave., Sunnyvale, CA 94089 U. S. A.)

${ }^{\dagger \dagger}$ Present address: Dynamic Material Research Group, Special Division for Human Life Technology, National Institute of Advanced Industrial Science and Technology (Midorigaoka, Ikeda, Osaka 563-8577, Japan)
} 